\title{
Art as Science Project: The Evolution of Darwin by Esther Solondz
}

\author{
Mick Wycoff
}

Published online: 12 Feruary 2008

(C) Springer Science + Business Media, LLC 2008

It was a global warming kind of $90^{\circ}$ late-September afternoon on the campus of Boston University. With the Red Sox in first place, nobody in the crowd of fans swarming toward Fenway Park seemed to notice a collection of blurry images somewhat randomly decorating the concrete seats and walls of Metcalf Plaza in front of the science building. The one exception was a diehard Yankees fan and evolutionist there to meet Esther Solondz, the artist responsible for some 80 portraits of his friends, colleagues, rivals, successors, and intellectual forebears (Fig. 1). Niles Eldredge was looking for his main man, Charles Darwin, but nearly a year after the project's start, the information, or message - drawings of photos on cloth — was succumbing to the medium-iron filings overlain with pillars of salt that burned a rust image onto the concrete. The rains of spring and summer had intervened. Some of the cloth froze solid and slowed the process. Somebody had stolen one of the Richard Dawkins portraits before it got to rust. The image of Daniel Dennett had severely deteriorated. What remained now, a spectral collection of faded, weathered faces seemed distorted, almost melted by time and the physics of change. (Images and the artist's blog may be viewed at http://www. BU.edu/Darwin.)

When Solondz showed up, she walked over to Eldredge and said, "I recognize you from your picture!" For a while, they just wandered around looking at the faces, trying to figure out who was who. The artist has moved on to new projects and said now she could not remember everyone she researched for the show last year. Besides, "weird things have happened to some of them." Many images

M. Wycoff $(\bowtie)$

433 East Saddle River Road,

Ridgewood, NJ 07450, USA

e-mail: meldredge@earthlink.net came out strangely bloated or distorted, others have diffused into virtual anonymity, and a few are defaced with cartoon balloon captions. At first, Eldredge was batting about 100 on the recognition scale and he could not identify Darwin or his own portrait, but - as is often the case with both art and science-patient observation led to clearer vision. There was Stephen Jay Gould, uncharacteristically wearing a tie, and one of the surviving Dawkins heads. Solondz said she mostly tried to stick to one image per scientist. But since Darwin was the star, there is a whole wall of him, and since the devil is in the details, when it came to Dawkins, the medium decided not to cooperate, and, she laughingly recalls, "for some reason, every image I put down didn't work. It became sort of this funny thing where he looked demonic...you know, all the filings filled in....and I became sort of obsessed with trying to get him on there."

You might call Esther Solondz a serious artist with an irreverent sense of humor. Her work appears in the collections of The Harvard University Art Museum, at the Rhode Island School of Design (RISD), and at De Cordova Museum and Sculpture Park in Lincoln, MA. She shows regularly at the Gallery NAGA in Boston and gets great reviews. And her art has intersected science for years as she explored the properties of salt, first with children's shoes and clothes covered in crystallized brine, then with rust pictures of anonymous women. But The Evolution of Darwin is different. First, there is the fact that the art press and followers forgot to show up (although Solondz reports that the science faculty from the Metcalf Science Center who attended her artist's reception last April knew almost all of their own off the bat). Then there is the crossover in subject matter - the installation depicts only known scientists whose work bears on evolution. To top it off, the project was born out of a joke. Solondz does seem playful-a 


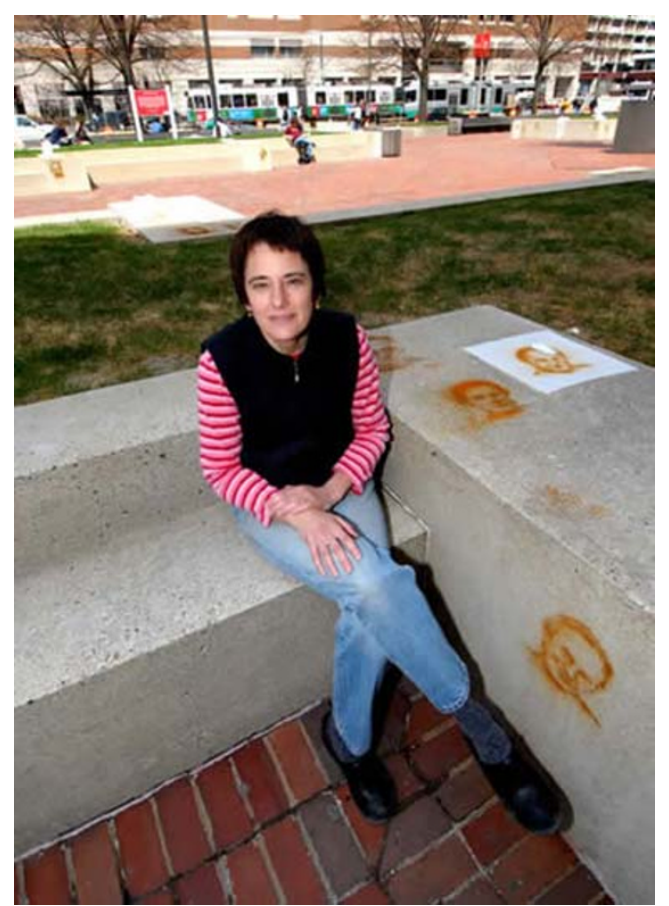

Fig. 1 The artist beside images of Richard Dawkins (http://www.BU. edu/Darwin)

gamin build, her light laugh, and quick smile make her seem more like one of her own RISD photography students than the dedicated studio artist and fiftyish mother of teenagers that she is. Yet there is a spark of the scientist in her eyes: fearless intelligence and a deep spirit of inquiry that likes to follow the thread of logic.

That is how Solondz got to thinking about natural processes and miracles. A few years back, she was so surprised when her first batch of rust heads on cloth released iron filing images right onto their beautiful, translucent beeswax basins that it felt like a miracle. She looked back on unusual stories she had heard about the miraculous appearance of sacred images and thought, "wouldn't it be funny if instead of that, it was Darwin on the tortilla?" She laughs and says, "from that, this project came. I said it would really be great if the images were this organic process, very not supernatural, but for people who embrace the real world, as opposed to the supernatural world." That inspiration kicked off an experimental era of neighborhood guerilla art. Solondz recalls placing the ironlined fabric pictures covered with rocks and salt bricks on the sidewalks of town: "It was very fun. Nobody stopped me. I started doing scientists in general-Marie Curie and Maria Gopert Meyer, putting them in crosses on the road." Like any science experiment, it took a period of trial and error, and a while to perfect the technique. Meanwhile, Solondz had some catching up to do. She says, "my background in evolution was zero, and I started reading about it really to do this project. That got me completely hooked, and I've been reading ever since."
Why is Solondz so attracted to evolution? Much of it may be metaphor - she views multiple pictures (based on a single drawing) as the "genotype" whose behavior and survival can be examined under varying environmental conditions. She called two images of Rachel Carson "clones," then affectionately dubbed them the "Doublemint twins." These are artistic tropes, not science. But, like Darwin in his day, Solondz truly is fascinated with transmutation. "The work that I've been doing for the last five or six years has been very much about things that transform," she affirms. "I like the idea of taking materials that are organic and seeing what will happen to them." She enjoys collaborating with natural processes because "sometimes something better comes out" than when you have complete control. Trace the arc of her work and you can see Solondz has drawn ever closer to nature. Starting as a student of film, she turned first to photography, then fine art with an increasingly technological and scientific bent. It was simple at first. Solondz speaks of the thrill of one early canvas as she resonated with the empty space produced when she removed a rock she had painted around. "I'm interested in things that leave their own trace," she observes. By now, she says, "it is to the point where it's starting to become sort of an overlap with science."

Solondz thinks back fondly to the huge salt crystals she managed to grow on one child's dress for the 2003 show They Left Their Clothes by the Water and how she started making salt stalactites by hanging a thread from a basin of supersaturated salt water (Fig. 2). Some of them grew to $12 \mathrm{ft}$, she recalls. "It became sort of like a gardening project: I'd go in, I'd climb up my ladder every day, I'd water the stalactites." Like Darwin's Down House, the studio is attached to a spacious garden, and Solondz walks it every day. Like Darwin, she possesses a scientist's passion for observation and a keen eye for change, always looking for something else lost or happening, saying "it's only exciting because it's so incremental." Her most recent project again represents a step closer to nature and also holds its parallels with Darwin's life at Down House. Last summer, at her retreat in New Hampshire, Solondz was working in her studio with the barn doors wide open on the garden when something zoomed in and buzzed her workspace, raising the thought of bats. After deciding it was a hummingbird, Solondz hit on a plan for collaboration. She stocked up on plenty of red-dyed hummingbird nectar and rigged up a particularly wobbly feeder right over the cloth she was painting with mud. The plan was for the mud to seep down through the cloth onto the handmade Japanese Kochi paper below and transmit not only an image somebody could actually buy to take home and display, but create a picture mediated by uncertainty. If the feeder tipped enough during the bird's visits, nectar would dribble down to add splashes of color and yet another contingent element not 
Fig. 2 Salt blocks formed in the artist's studio (http://www.BU. edu/Darwin)

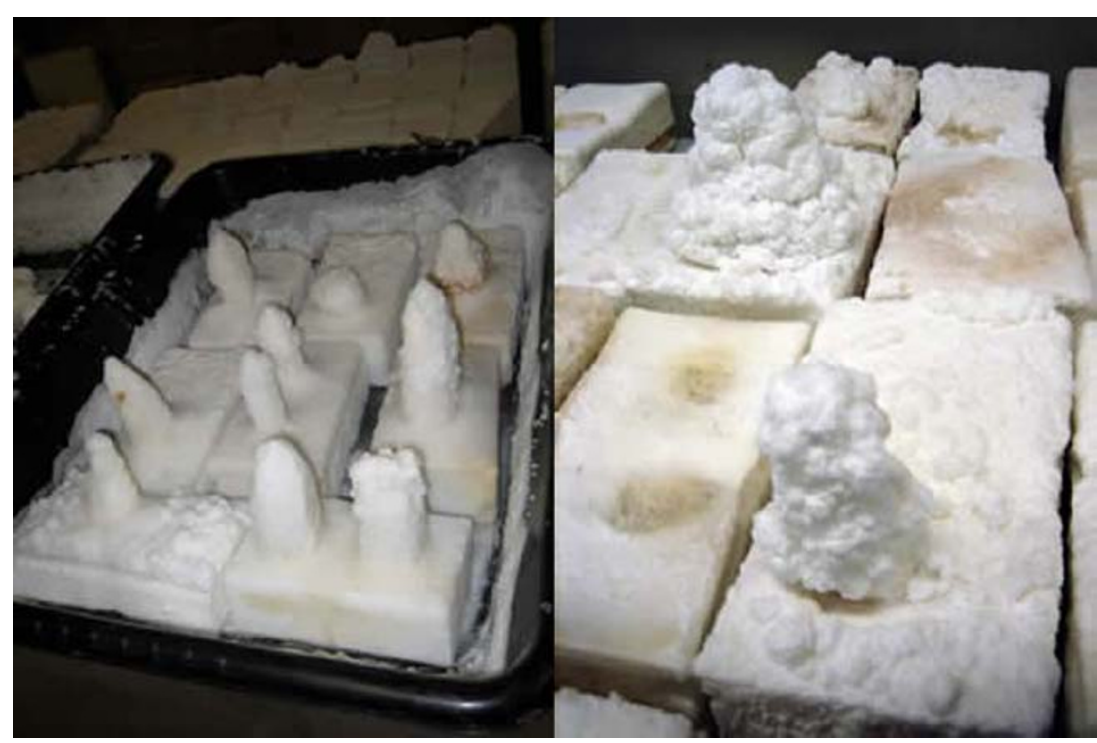

fully under the artist's control. The experiment succeeded. In January, NAGA Gallery opened a show that featured a lovely, pink-tinged image of a woman's head entitled "Duchess of Portland," rendered in mud and hummingbird nectar on Kochi paper (Fig. 3). "I've never heard of anybody that had a domestic hummingbird," Solondz marvels.

Like Darwin, Esther Solondz turned to her immediate surroundings to establish an intimate relationship with the environment - tending it, observing it, and communing with it for the inspiration that leads to the profound insights nature can yield. Now the artist-turned-naturalist wants to create a direct tribute in honor of the bicentennial of Charles Darwin's birth on February 12, 2009. She has two intriguing ideas that spring from a theme that came to her in

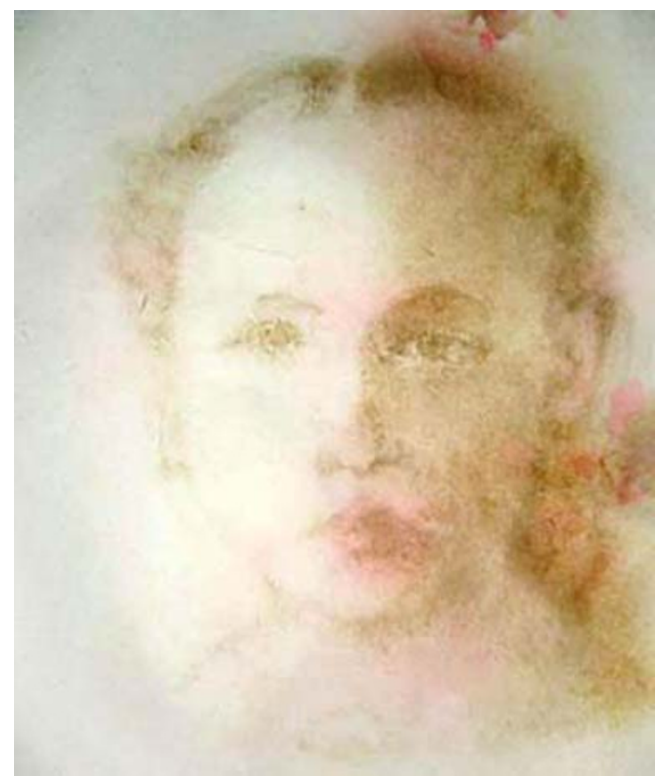

Fig. 3 "Duchess of Portland" by Esther Solondz, 2007, mud and humingbird nectar on Kochi paper (Gallery NAGA) a brief waking moment at three in the morning last fall: "The Seeds of Darwin." One thought is so grand that it challenges the possible. The other is likely to turn up on the BU campus next year. Imagine that somehow you could get hold of enough seeds that were actually grown at Down House so they could be distributed throughout the world and all germinate in time for Darwin's bicentennial birthday. Of course, there are a million caveats and difficulties. What about invasive species issues, coordinating the project, generating all the seeds, who would plant them, and how, and would they plant them? But what a wonderful tribute and celebration that would be! One facet of the "Seeds of Darwin" project seems imminently manageable and reflects Solondz' early interest in sculpting and her current passion for plants and mud. "I'm going to be working at BU and I'm sort of thinking of making a sixfoot head of Darwin out of mud and maybe impregnate it with these seeds and let it dissolve into a bed, and then it will grow," she says.

The hot afternoon on Commonwealth Avenue wanes as the crowd surging toward Fenway Park swells. It is time for Solondz and Eldredge to get out of Boston. Before they part ways, he urges her to visit Down House and pursue her ideas with a list of contacts he gives her. In turn, she asks him to appeal to his readers for thoughts about how to achieve her "Seeds of Darwin" goals by sending their ideas to her attention at EEO (mick@nileseldredge.com). Both agree to meet again in 2009 to raise a glass in honor of their intellectual hero, Charles Darwin.

\section{Images Pictured in the Evolution of Darwin}

Annie Montague Alexander b. Dec. 29 1867, Honolulu, Hawaii, d. 1950, was an heir to the C\&H Hawaiian sugar 
empire. Her great interest in natural history ranged from fossils to California native plants, and she helped establish and endow the U.C. Museum of Paleontology at Berkeley in 2008. She and her life companion Louise Kellogg collected, documented, and donated more than 22,000 plant, animal, and paleontological specimens to the University's scientific collections, naming many new species along the way. Alexander celebrated her 80th birthday in the field.

Maydianne Andrade b. Kingston, Jamaica, has a Ph.D. in neurobiology and behavior from Cornell University. She is an associate professor of ecology and evolutionary biology at the University of Toronto at Scarborough where she mainly studies black widow spiders - their cannibalism and other behaviors affecting sexual selection, mating signaling, and foraging. She was honored as one of Popular Science Magazine's "brilliant 10" in 2005. Her work examining how social, sexual, and genetic processes modulate in the ecological setting represents one of the exciting new directions of evolutionary study.

Robert Axelrod b. 1943, has a Ph.D. in political science from Yale and is Professor for the Study of Human Understanding at the University of Michigan. His interdisciplinary work on the evolution of cooperation has been widely cited. Influential books include The Evolution of Cooperation (1984) and Harnessing Complexity: Organizational Implications of a Scientific Frontier (2000). He is a member of the National Academy of Sciences, and a MacArthur award-winner. Applying game theory models to evolutionary scenarios, he has come up with insights based on "tit-for-tat" behavior and has explored implications of the "prisoner's dilemma."

Sarah Blaffer-Hrdy b. July 11, 1946 Dallas, TX, holds a Ph.D. in anthropology from Harvard. Her thesis work on langurs at Mount Abu, India, led to her first book about primate infanticide as an adaptive behavior: The Langurs of Abu (1977). Later research extended the model to human behavior, and Hrdy was labeled an extreme feminist, but time has proven many of Hrdy's assertions correct, suggesting there are adaptive advantages for a male primate who kills his deposed predecessor's babies as it causes females to go into estrus early, whereas female infanticide in humans and other primates is related to enhanced survival of the mother and older offspring.

Rachel Carson b. May 27, 1907, Springdale, PA, d. 1964, started as a science writer with an M.A. in zoology from Johns Hopkins University and rose to become the head science writer for the U.S. Fish and Wildlife service. Her prize-winning book The Sea Around Us led her to become a full-time writer in 1952. Her passionate diatribe against chemical pollution, Silent Spring (1962), grew out of her love of nature and conviction that humanity must consider itself part of the larger ecosystem. Hers was one of the first voices raised in the modern ecological conservation movement, and she testified before Congress in 1963. Her long physical struggle with breast cancer ended her life in 1964 (Fig. 4).

Erwin Chargaff b. Aug. 11, 1905 Czernowitz, Bukovina (now Ukraine) d. 2002, was another of the seminal scientists excluded from the 1962 Nobel Prize for the discovery of the structure of DNA. Chargaff was a Viennatrained chemist who emigrated to the U.S. during the Nazi era. He spent the bulk of his career thereafter at Columbia University and is known for "Chargaff's rules" that determined near-equivalencies between the two base pairs of DNA (guanine $=$ cytosine and adenine $=$ thymine), and that the composition of DNA varies with varying species, making it more likely that DNA rather than protein carried the genetic information, which contributed to solving the DNA puzzle. He resented being ignored by the Nobel committee, as the prize can only be split three ways.

Martha Cowles Chase b. 1927 in Cleveland Ohio, d. 2003, was an American geneticist with a Ph.D. from the University of Southern California. She gained near-equal credit with her boss Alfred Hershey working at Cold Spring Harbor, Long Island, on the famous "blender experiment" that proved in 1952 that DNA is the carrier of genetic information in viral reproduction. This milestone contributed to James Watson and Francis Crick determining the structure of DNA at Cambridge, England the following year.

Sallie (Penny) Chisholm, Ph.D., SUNY Albany, is considered one of the world's top biological oceanographers. Her discovery with colleagues R. J. Olson and H. M. Sosik that small plankton, such as the photosynthetic bacteria Prochlorococcus, contribute far more marine productivity than had previously been realized, demoted silicaceous diatoms from being considered the most important phytoplankton in the sea. There are important

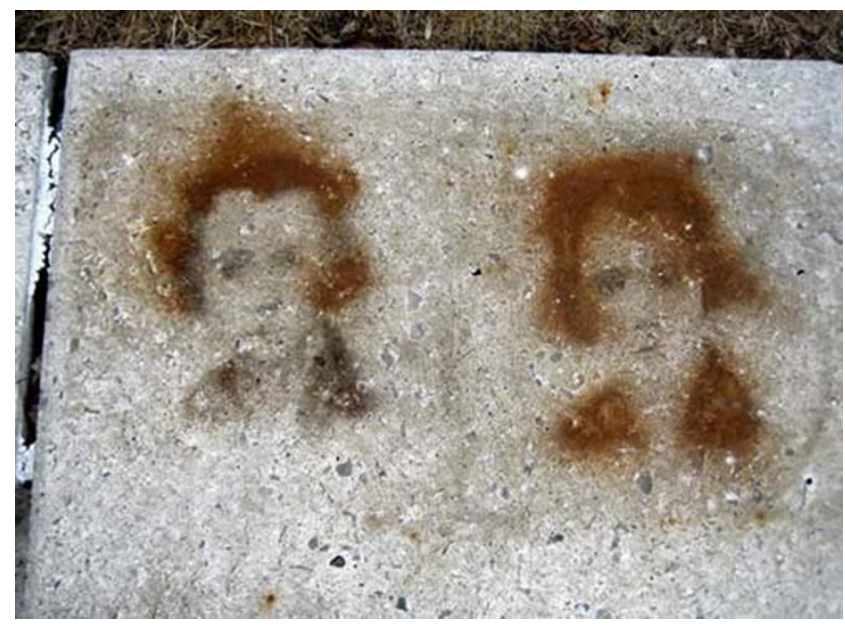

Fig. 4 Rachel Carson "clones" drawn in iron filings from a single template (http://www.BU.edu/Darwin) 
implications for global warming and understanding Earth's atmosphere, as large amounts of carbon are cycled through Prochlorococcus, which may also play an important role in the global nitrogen cycle.

Marie Curie b. Maria Sklodowska, Nov. 7, 1867, in Warsaw, Poland; d. 1934, entered the University of Sorbonne in Paris in 1891 where she met and soon married Pierre Curie. Marie became the first woman to teach there, and working with Pierre, she explored the properties of radioactive materials, discovering the elements radium and polonium. She and Pierre shared the 1903 Nobel Prize in Physics with Antoine Henri Becquerel, the discoverer of spontaneous radioactivity. Pierre was killed in a horse carriage accident in 1906. Marie worked unabated until her death and was awarded the 1911 Nobel Prize in Chemistry for her continuing work with radioactive elements (Fig. 5).

Charles Darwin b. Shrewsbury, England, Feb. 12, 1809 d. 1882 and was buried in Westminster Abbey to honor his discovery of natural selection as the engine of evolution, discovered earlier but only published in his famous $O n$ The Origin of Species (1859). He planned to become a minister, but his studies at Cambridge - botany with Reverend John Stevens Henslow and geology with Reverend Adam Sedgwick - prepared him for his lucky voyage of discovery in South America on the Beagle. By the time he reached the Galapagos Islands, the young naturalist was already an evolutionist, although he did not come up with the mechanism of natural selection until reading Malthus' "Essay on the Principle of Population" (Fig. 6).

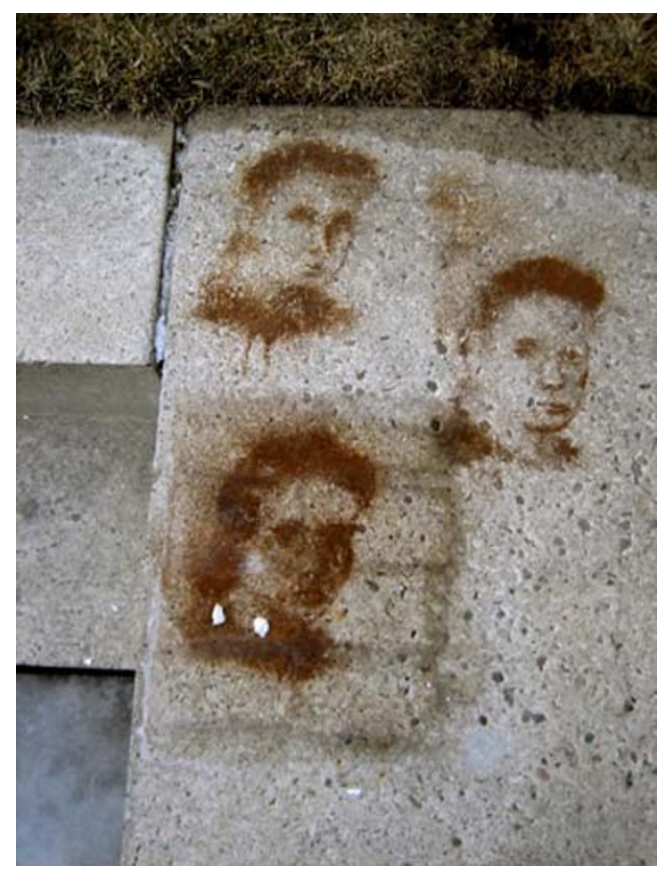

Fig. 5 "This is the third clone of Marie Curie. It is amazing to me how different each of them have come out." (quoted from the artist's blog at http://www.BU.edu/Darwin)
Richard Dawkins b. March 26, 1941, Nairobi, Kenya, and educated in England, took both his undergraduate and Doctorate degrees at Oxford. Starting as a student of animal behavior, Dawkins was soon immersed in evolutionparticularly the role of genes - and wrote the 1976 bestseller The Selfish Gene, which argues that genes, in effect, compete for representation in the succeeding generation. That position has gained him a wide popular audience along with vigorous debate within the evolutionary community. Like Daniel Dennett, Dawkins is an avowed atheist whose latest book, The God Delusion (2006), has commanded great sales and media attention (Fig. 7).

Daniel Dennett b. March 28, 1942, Boston, MA, holds a B.A. in philosophy from Harvard and a D.Phil. from Christ Church, Oxford. Famed - or perhaps infamous-for his uncompromising atheism, Dennett's name and stance are often associated with Richard Dawkins in their shared extension of Darwin's biological model to culture and wider scientific applications. Their emphasis on adaptation as a perfecting mechanism in evolution stands in contrast to views held by critics such as Richard Lewontin and Stephen Jay Gould who argued that adaptation is influenced by limiting factors that often make it contingent upon other circumstances (Fig. 8).

Theodosius Dobzhansky b. Jan 25, 1900, Nemyriv, Ukraine, d. 1975, was a brilliant population geneticist whose formal education ended with a college diploma in Kiev. With aid from the Rockefeller Foundation, he and his wife emigrated to the U.S. in 1927, when "Doby" began working on fruit flies (Drosophila) with Thomas Hunt

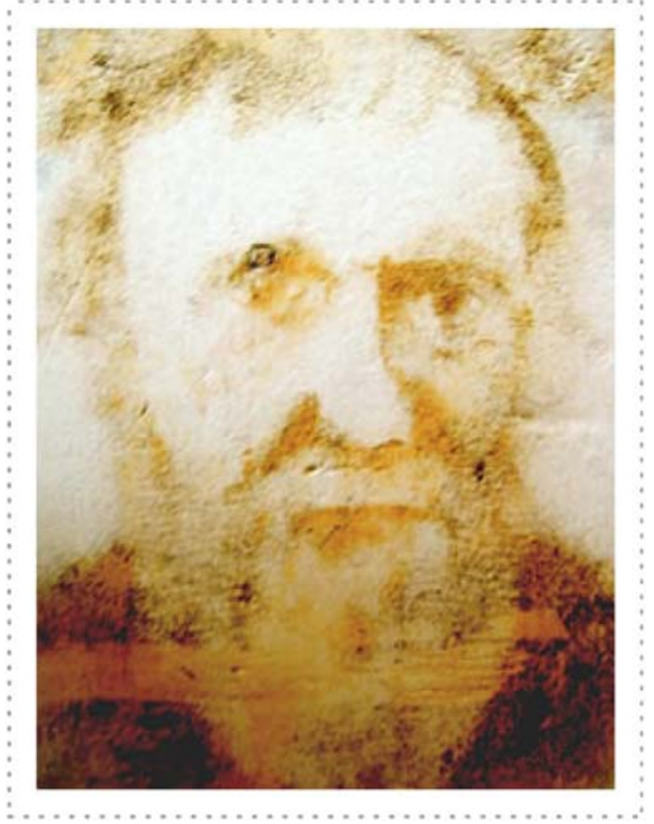

Fig. 6 Charles Darwin by Esther Solondz (http://www.BU.edu/ Darwin) 


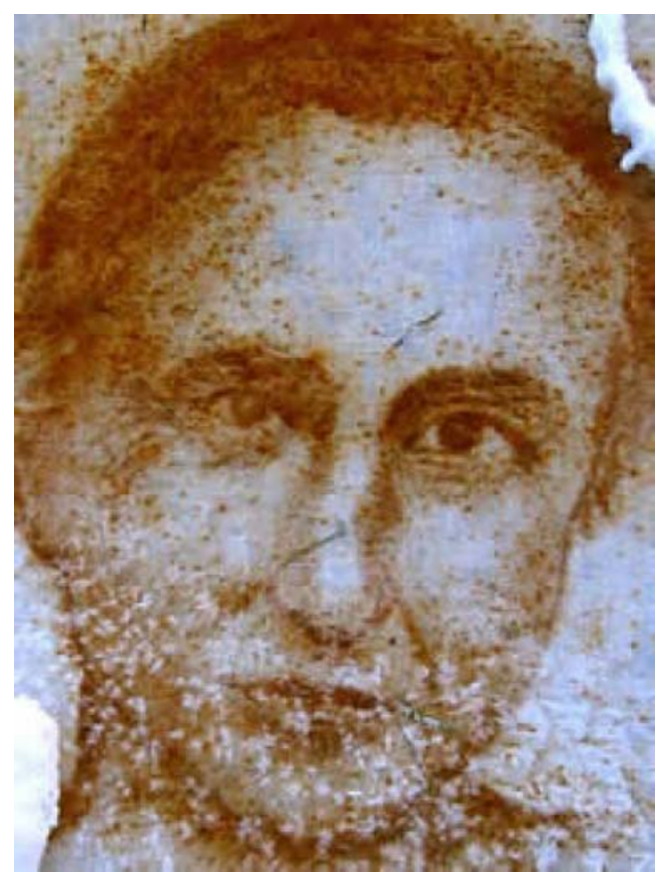

Fig. 7 Richard Dawkins by Esther Solondz (http://www.BU.edu/ Darwin)

Morgan at his Columbia University laboratory. He published Genetics and the Origin of Species in 1937, one of the keystones of the modern evolutionary synthesis. In 1973, he published an article in American Biology Teacher entitled "Nothing in Biology Makes Sense Except in the Light of Evolution," a conviction that still resonates with ringing clarity.

Georgia M. Dunston b. 1944, Norfolk, VA, received the first Ph.D. in genetics granted an African-American at the University of Michigan. She is founding director of Howard University's National Human Genome Center and Director of Molecular Genetics. Dunston works on immunogenetics, population genetics, and the genetics of

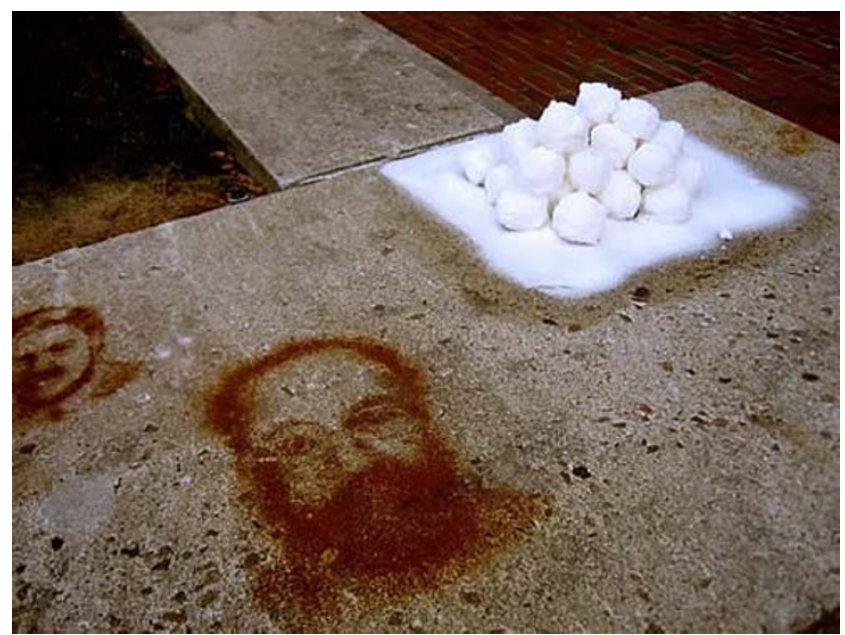

Fig. 8 Daniel Dennett by Esther Solondz (http://www.BU.edu/ Darwin) complex diseases. Recent studies include work on prostate cancer, diabetes, breast cancer, and asthma with an emphasis on African Americans. She also works with Genomic Research in the African Diaspora (GRAD) - a biobank to trace genetic factors in diseases such as diabetes and prostate cancer that disproportionately affect African Americans.

Niles Eldredge b. August 25, 1943, Brooklyn, NY, took his undergraduate B.A. and Ph.D. in geology at Columbia University and has been a curator at the American Museum of Natural History since 1969. In 1971, Eldredge published a paper based on his Ph.D. research that laid out the basic concept of what Gould later dubbed "punctuated equilibria," and the following year, Eldredge and Stephen Jay Gould jointly published an expansion of the concept to which both authors contributed. The idea-now often called punctuated equilibrium - challenges the traditional view of gradual Darwinian evolution: slow, steady change over long intervals of geological time. Eldredge's work shows that often species show stasis - little or no changefor millions of years before a sudden appearance of a new descendant (Fig. 9).

Ronald Fisher b. London, England, Feb. 17, 1890, d. 1962, graduated from college at Cambridge in 1913 where he got hooked on eugenics, a lifelong prejudice. He is famed as a statistician, evolutionary biologist, and geneticist. Known with Sewall Wright and J.B.S Haldane for work on the modern evolutionary synthesis, his contributions to population genetics are still important. Fisher also

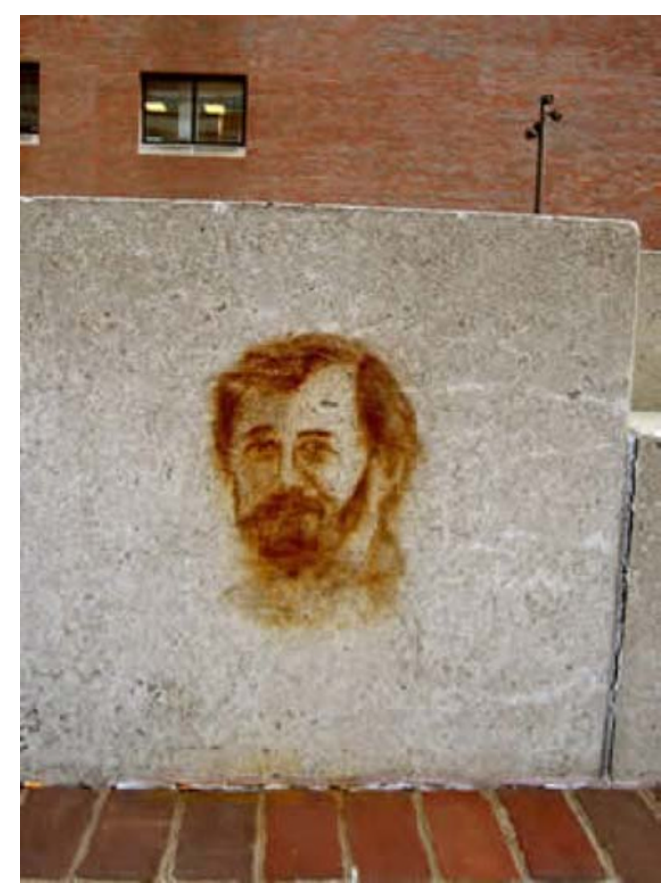

Fig. 9 Niles Eldredge by Esther Solondz (http://www.BU.edu/ Darwin) 
taught all of science how to use statistical analysis and published the first application of computers to biology in a 1950 paper on gene frequency.

Dian Fossey b. San Francisco, CA 1932, d. 1985, had a BA in occupational therapy from San Jose State College and worked with children when she got interested in mountain gorillas, went to Africa, met Louis and Mary Leakey, and ultimately raised funds to work first in Zaire and then in Rwanda studying the little-understood gorillas. Her hard work and dedication led to amazing success in making contact with and documenting the hidden world of the mountain gorilla, an endeavor that became her life's work and made her world famous. Her book Gorillas in the Mist (1983) is the top-selling gorilla book in print. Deeply involved in African and Rwandan conservation politics, Fosse was murdered in her Rwanda cabin, a mysterious attack that remains unsolved.

Rosalind Franklin b. July, 25, 1920, London, England, d. 1958, was a noted chemist with a Ph.D. from Cambridge, working in the same laboratory as Watson and Crick also on the structure of DNA. Her work pinpointed almost everything except how the bases paired inside the helix, and Watson and Crick acknowledge that her work was crucial to their solving the puzzle. It is said she never knew that Crick and Watson had seen and used her data before it was published alongside their own breakthrough discovery in an April 1953 issue of Nature. Franklin died of cancer at 37, and the Nobel Prize awarded to Wilson, Watson, and Crick in 1962 excluded Franklin as it is not granted posthumously.

Walter Gilbert b. March 21, 1932, Boston, Ph.D., University of Cambridge, was working in particle physics when interactions with Jim Watson got him interested in how messenger RNA works. His focus has been molecular biology ever since, and his work won him the 1980 Nobel Prize in Chemistry with Frederick Sanger and Paul Berg. His DNA sequencing techniques revolutionized molecular biology, advanced DNA study, and led to the Human Genome Project. He was a founder of the pioneering genetic engineering corporation Biogen but quit in 1984. He remains a professor (emeritus) at Harvard's Department of Molecular and Cellular Biology.

Richard Goldschmit b. Frankfurt-am-Main, Germany, April 12, 1878, d. 1958, was noted for his pioneering work integrating evolution with genetics and development. $\mathrm{He}$ fled Nazi Germany and settled into research at U.C. Berkeley where he published his "hopeful monster" model of macroevolution in The Material Basis of Evolution (1940). He believed that microevolution-the constant small changes in a population - could not lead to speciation but that rapid, large changes could. Stephen Jay Gould defended this much-maligned position with the defense that small changes early in embryology may yield profound differences among adults.
Jane Goodall b. April 3, 1934 London, England, got a $1965 \mathrm{Ph} . \mathrm{D}$. in ethology from Cambridge University and established the Gombe Stream Research Center in Tanzania soon thereafter. A leader in the field of primatology, she first established that chimpanzees, like humans, have minds, emotions, friends and enemies, social organization, and lasting family relationships. In 1977 she established the Jane Goodall Institute for Wildlife Research, Education and Conservation, and she is a much-honored environmentalist who was named a United Nations Messenger of Peace in 2002.

Stephen Jay Gould b. Sept 10, 1941, New York, NY, d. 2002, got his Ph.D. at Columbia University and taught at Harvard where he was Alexander Agassiz Professor of Zoology. His work with Niles Eldredge of the American Museum of Natural History on their original theory of punctuated equilibria made him both a popular and controversial figure, as his superb success as a teacher and popular science writer brought a new view of evolution to students and the public while shaking the foundations of traditional paleontology. The much-challenged but now widely accepted theory states that evolution often proceeds in rapid bursts between long periods of stasis or little change (Fig. 10).

Asa Gray b. Nov. 18, 1810, Paris, NY, d. 1888, was the foremost American botanist of his day and Darwin's first, strongest supporter in the United States. Working at a time when the nation's flora was mostly unclassified, Gray wrote defining taxonomies, textbooks, and guidebooks. It was his interest in and knowledge of plant distributions that sparked a sustained correspondence with Darwin who later produced a copy of a letter to Gray in proof of his claim to have discovered the idea of natural selection before Alfred Russel Wallace. In spite of his evangelical Protestant faith, Gray had no problem reconciling his Darwinism with a profound rejection of atheism.

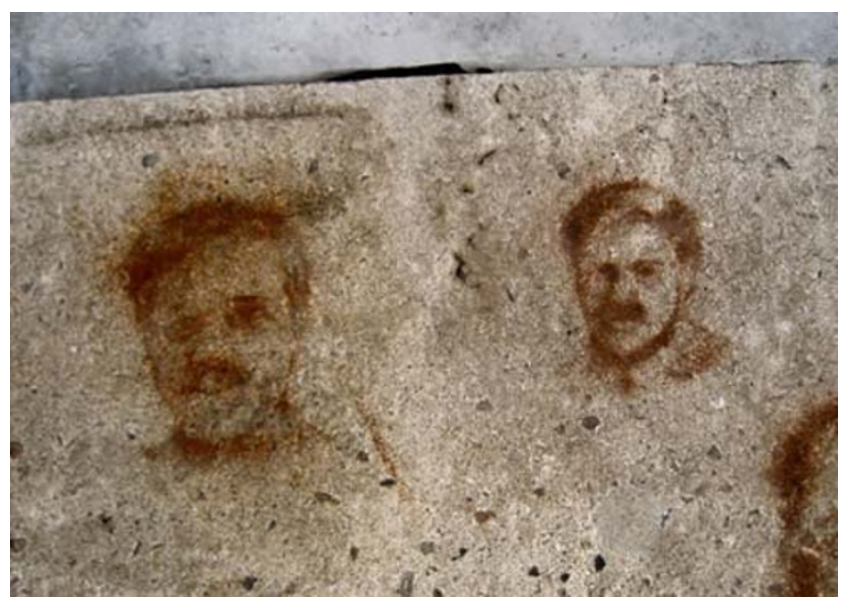

Fig. 10 Stephen Jay Gould by Esther Solondz (http://www.BU.edu/ Darwin) 
Ernst Haeckel b. Feb. 16, 1834, Potsdam, Germany (then Prussia), d. 1919, was trained as a physician in Berlin but soon left the field, then took a Ph.D. in zoology at the University of Jena where he spent his entire career as a systematic zoologist. Haeckel became Darwin's great champion in Germany. His encyclopedic field work and brilliantly drawn illustrations are famous, and he identified and illustrated literally thousands of species. Although now considered somewhat oversimplified, his idea and phrase "ontogeny recapitulates phylogeny" was useful at the time. His ideas about race, although quite wrong, typified the Victorian era, as did his rejection of natural selection.

David Haig b. Canberra, Australia 1959, was trained in Australia and did postdoctoral study at Oxford and at Harvard where he is now an associate professor of biology. His work on genetic imprinting shows that a DNA sequence can have conditional behavior so that certain genes have a different pattern of expression depending on whether inherited from the mother or father. Such expressions may affect development-including of human diseases - and the possibility has sparked present research regarding the involvement of genomic imprinting in conditions ranging from preeclampsia in pregnancy to mental dysfunctions such as autism.

J. B. S. Haldane b. 1892 Oxford, England, d. 1964, was from a notable Scottish family, and his first scientific training was assisting his respiratory physiologist father. Completing an education at Oxford interrupted by active service during WWI, Haldane returned to become a lecturer there, and he developed a mathematical approach to understanding natural selection. Contributions in respiratory physiology, evolution, and population genetics included identification of the location on chromosomes of mutations responsible for hemophilia and color blindness. Haldane is credited jointly with Ronald Fisher and Sewell Wright for developing the modern evolutionary synthesis.

William Donald Hamilton b. Aug. 1, 1936, Cairo, Egypt, d. 2000, held a Ph.D. from University of London where he read and was greatly impressed by the work of R. A. Fisher. His work on altruism among hymenopteran social insects prefigured that of E. O. Wilson, and his mathematical approach to quantifying animal behavior was as important as it was abstruse. Now a ruling maxim in sociobiology, "Hamilton's rule" says a gene for altruistic self sacrifice will spread through a population if the cost to the altruist is outweighed by the benefit to the recipient devalued by a fraction representing the genetic relatedness between the two.

Sir Fred Hoyle b. June 24, 1915, Gilstead, England, d. 2001, was trained as a mathematician at Cambridge. $\mathrm{He}$ was one of the leading astronomers of the twentieth century, enriching both formal science and mass culture. During WWII, he helped to develop radar and, thereafter, was founder of the Institute of Astronomy at the University of Cambridge. His work with William Alfred Fowler on the synthesis of elements in stars was seminal, although he did not share the 1983 Nobel Prize with Fowler. He also helped develop the theory of "panspermia" along with Chandra Wickramasinghe and Joan Oró. Hoyle was made a knight in 1972.

Sir Julian Huxley b. June 22, 1887, London, England, d. 1975, Julian was the brother of the author Aldous Huxley. Julian took an undergraduate degree at Oxford in 1908. He became the first Director-General of UNESCO, and his dedication to conservation was important to the startup of the World Wildlife Fund. As the grandson of Thomas Henry Huxley, Charles Darwin's champion, Huxley carried on the tradition by writing about the modern synthesis and popularizing Darwin's ideas, especially natural selection as the prime agent of evolution.

Thomas Huxley b. Middlesex, England, 1825 d.1895 was an important public figure who was trained as a biologist. Huxley is often referred to as "Darwin's bulldog" for his passionate defense of Darwin's ideas, crystallized in the famed 1860 debate with Archbishop Samuel Wilberforce. Huxley was a somewhat radical figure for the times, as his passion for the scientific method made him an agnostic who demanded rational, material explanations and rejected spiritualism. His own writings include Evolution and Ethics, nine volumes of collected essays and an autobiography published in 1903.

Steve Jones b. Aberystwyth, Wales, March 24, 1944, Ph.D., University of Edinburgh, is a professor in the Department of Biology, University College, London. He is a popular media figure with a number of books to his name and a regular science column in the London newspaper Daily Telegraph. Publications include In the Blood: God, Genes and Destiny (1997) and The Language of the Genes (2000). His studies of snails, fruit flies, and humans seek answers to how variation relates to environmental factors. Jones is one of the editors of the Cambridge Encyclopedia of Human Evolution (1994). His voice remains strong in the fight against creationism, which he has labeled "antiscience."

Motoo Kimura b. Nov. 13, 1924, Okazaki, Japan d. 1994, joined the faculty of the National Institute of Genetics in Mishima in 1949 and published an important paper extending Sewall Wright's evolutionary scenario to a "stepping stone" model. Drawing the attention of U.S. geneticists, Kimura went on to get a Ph.D. at the University of Wisconsin before returning to the National Institute of Genetics in Japan. His population genetics work on the "neutral theory of molecular evolution" was based on his conclusions that most evolution at the molecular level is the result of random processes such as mutation and genetic drift. 
Philip Kitcher b. 1947, London, England, Ph.D., Princeton, is a philosopher of science with an interest in evolution. He is the John Dewey Professor of Philosophy at Columbia University. His examination of what he calls "the apparent conflict between science and religion" has led to his strong stand against creationism and defense of secular humanism. At the same time, his concern with the ethics of science has led him to enquiries regarding human genome research and applications.

Mary Douglas Nicol Leakey b. London, England 1913, d. 1996, was the daughter of traveling artists. An accomplished illustrator herself, with little education but much exposure to prehistoric cave paintings and archaeological sites as a girl living in France, she trained in England as an archeological artist, then met and married Louis Leakey as his second wife. A lifelong record of remarkable fossil finds in Africa made her one of the premier twentieth century archaeologists; they include the early hominid skulls Proconsul africanus found in 1948 at Lake Victoria and Zinjanthropus, later renamed Australopithecus boisei, in 1959 at Olduvai Gorge.

Richard Leakey b. Dec. 19, 1944, in Nairobi, Kenya, lived life in the field from the first in the company of his paleoanthropologist parents Louis and Mary. Richard made his first significant fossil find at the age of 6 . A born rebel, he disliked the racism of his fellow colonial students and dropped out to become a professional tracker/hunter at age 16, going on to lead safari treks until he finished his education and returned to the family business. A chance flyover of Lake Turkana sparked a suspicion it might be fossiliferous, starting a 30-year excavation program that yielded Richard's greatest discovery, "Turkana boy," a Homo ergaster skeleton, one of the most complete ever found.

Susan Lindquist b June 5, 1949, has a Ph.D. in biology from Harvard and has done pioneering work in protein folding-demonstrating that alternative protein conformations have profound and unexpected effects in fields as wide ranging as human disease, evolution, and biomaterials. Former Director and continuing member of the Whitehead Institute associated with MIT, she is an expert in the biology of protein folding, heat shock proteins, and prions. Her work has major implications for oncogenesis and for evolutionary biology.

Lynn Margulis b. March 5, 1938, Chicago, IL, is a cell biologist with a Ph.D. from U.C. Berkeley. Now at University of Massachusetts in Amherst, she was always an original thinker. Although it was slow to be recognized, she came up with a theory of the origins of the eukaryotic cell now known as one of the great achievements of twentieth century evolutionary biology. Her research shows that single-celled bacteria-prokaryotes-fused in symbiotic relationships that evolved into eukaryotes - cells with a nucleus. She is also known for her work with James Lovelock on the Gaia theory that views all of Earth as a single organic entity whose very atmosphere is a byproduct of evolution.

Ernst Mayr b. July 5, 1904, in Kempten, Germany; d. 2005, earned a medical degree at the University of Griefswald in 1925, then quickly followed with a Ph.D. in Zoology at the University of Berlin. Mayr's defining field experience collecting birds and botanical species in New Guinea helped him nail down the biological definition of a species in his 1942 book Systematics and the Origin of Species. Along with Theodosius Dobzhansky and George Gaylord Simpson, Mayr is considered one of the architects of the modern synthesis in the United States. Much of his important work was done at the American Museum of Natural History before he moved on to Harvard University.

Barbara McClintock b. June 16 1902, Hartford, CT., d. 1992, got her Ph.D. in botany at Cornell. She became a member of the National Academy of Sciences in 1944 and was the first American woman to win an unshared Nobel Prize, the 1983 Prize in Physiology or Medicine, for her cytogenetic studies of corn (maize). McClintock showed that genes can change position, as shown in varying corn kernel colorations under controlled experimental conditions. McClintock demonstrated the role of telomeres and centromeres on chromosomes and produced the first genetic map of maize.

Gregor Mendel b. Johan, July 22, 1822, in Heizendorf, Austria (now Hyncice, Czech Republic) d. 1884, came from a poor farming family and joined a monastery where he took his monk's name of Gregor. The scholarly Augustinian order allowed Mendel to spend the years 1856-1863 cultivating some 28,000 pea plants as he investigated heredity, variation, and evolution in plants. He essentially discovered the gene and came up with the terms and definitions of dominance and recessiveness. Mendel published his results in the obscure "Journal of the Natural History Society of Brno," and they sank virtually without a trace, until rediscovered by several biologists in 1900 .

Thomas Hunt Morgan b. Sept. 25, 1866, Lexington, KY, started his career as an embryologist with a Ph.D. from Johns Hopkins. Running his genetics laboratory at Columbia University - the famed "fly room" filled with Drosophila-he and his colleagues isolated chromosomes and proved they were the site of genes that carry the information of the transmission of life. Awarded the 1933 Nobel Prize in Physiology or Medicine, he was the first to receive it for genetics research.

Desmond Morris b. Jan 29, 1928, Purton, England, got his doctorate in zoology at Oxford and worked as a curator of mammals at the London Zoo until just a year before publishing his 1967 blockbuster The Naked Ape-a book 
whose scenario of man driven by animal instincts proved as popular as his science was debatable. Already a media figure since his 1950s TV show "Zoo Time," Morris never gained much traction in the academic community, although he was on the forefront of scientific interest in the evolution of behavior. His books about cats, dogs, horses, body language, and more continue to please a receptive public.

Masatoshi Nei b. 1931, Kyushu Island, Japan, Ph.D. in quantitative Genetics, Kyoto University, is head of the Institute of Molecular Evolutionary Genetics at Pennsylvania State University. His fame began in 1972 with his measurement of the genetic differentiation between species, referred to as "Nei's genetic distance," which makes it possible to estimate the origins of populations and the times of their divergence from common ancestors. Nei was a founder of the journal Molecular Biology and Evolution and the Society for Molecular Biology and Evolution and was made a member of the National Academy of Sciences in 1997.

Mark Norell b. July 26, 1957, St. Paul, MN, has a Ph.D. from Yale University and is a vertebrate paleontologist at the American Museum of Natural History. Norell's field experience dates back to his teen years, and he has written several books about his fossil discoveries, which include the theropods, Shuvunia and Mononykus, just two of the rich finds in the American Museum's Gobi desert dig, ongoing in cooperation with Mongolian experts since 1990. Most exciting of Norell's work is the discovery of evidence that feathered dinosaurs were precursors of modern birds. Norell also curated the 2005 AMNH exhibition, "Dinosaurs: Ancient Fossils, New Discoveries."

Susumo Ohno b. Feb. 1, 1928, to Japanese parents in Seoul, Korea; d. 2000, received a veterinary degree at the Tokyo University of Agriculture and Technology and a Ph.D. in genetics from the Hokkaido University Faculty of Sciences. He emigrated to the U.S. after WWII and became a U.S. citizen. One of the first geneticists to identify the key role of gene duplication in molecular evolution, Ohno coined the term "junk DNA," and his study of the chromosomes of mammals was important for recognizing that most of the DNA in higher organisms does not consist of coding sequences. He was elected to the National Academy of Sciences in 1981.

Joan Oró b. Oct. 26, 1923, Lleida, Spain, d. 2004, got a Ph.D. in biochemistry at Baylor University in Houston and went on the establish the Department of Biophysical and Biochemical Sciences at the University of Houston in 1956. His work in prebiotic chemistry led to his synthesis of one of the DNA bases, adenine, and opened the way for future synthesis of all DNA bases. Oró is noted for his contributions to the "panspermia theory" that the basic elements of life may have arrived on Earth in comets. His work with NASA helped to establish the probability that there is no life on Mars.
Richard Owen b. Lancaster, England, July 20, 1804, d. 1892, was trained as an anatomist and surgeon in Edinburgh. He joined the Royal College of Surgeons in London and had catalogued its entire vast Hunterian Collection of human and anatomical specimens by 1830 . He became a famous taxonomist, describing and naming many living and fossil vertebrates including those Darwin brought back from the Beagle trip, although Owen himself rejected Darwin's ideas about natural selection. Instrumental in starting the British Museum, now called the Natural History Museum, Owen coined the words "dinosaurus" and "homology," which he described as the same organ in different animals, i.e., a bat's wing, a whale's flipper, and the human arm.

Steven Pinker b. Sept. 18, 1954, Montreal, Canada, has a Ph.D. in experimental psychology from Harvard where he now teaches. Famed for his theories of language and the mind, his discussions of the relationship between evolution, thought, and language in his books How the Mind Works (1997) and The Language Instinct (1994) make the case that mental and language behaviors evolved in response to paleohuman needs, although his ideas remain controversial. His work is an extension into the realm of evolutionary psychology of Noam Chomsky's idea that language is an inherited ability, created and refined by natural selection.

Joan Roughgarden b. Paterson, N.J., March 13, 1946 as Jonathan, is Professor of Biological Sciences at Stanford University, completing her transgender process and name change in 1998. Areas of expertise include theoretical ecology and evolution. Recent work and her latest book, Evolution's Rainbow (2005) examines diversity, gender, and sexuality in nature and people to make the argument that Darwin's ideas about sexual selection were often mistaken, narrow, and overly reflective of the prejudices and misconceptions of the Victorian era.

Vincent Sarich b. Chicago, IL, 1934, has a Ph.D. in anthropology from U.C. Berkeley, becoming a professor emeritus there in 1994. His joint work on the "molecular clock" with his former Ph.D. supervisor, Allan Wilson, led to the conclusion that apes and humans shared a common ancestor no more than 5 million years ago, rather than the commonly held timeframe of 20-25 million years ago. His belief that racial differences signal the beginning of speciation and a favorable review of the much-criticized study of human intelligence, The Bell Curve, make him a controversial figure among American anthropologists.

Eugenie C. Scott b. 1945 and raised in Wisconsin, she took a Ph.D. in physical anthropology at the University of Mississippi and was a university professor before becoming the Executive Director of the National Center for Science Education (NCSE). Scott is a nationally recognized expert on the creation/evolution controversy; her books, articles, interviews, and outreach have won many awards. Scott and 
other NCSE staff served as education and science consultants in the 2005 Kitzmiller v Dover Area School District case in Pennsylvania, which ruled that intelligent design has no basis in science and no place in the school science curriculum (Fig. 11).

Chris Schneider has a Ph.D. from U.C. Berkeley and is now on the staff at Boston University where he specializes in ecology and evolution of reptiles and amphibians, molecular systematics and population genetics, tropical biology, and conservation. His current research examines evolutionary processes that shape patterns of species diversity in tropical rainforests. This large, collaborative study is designed to identify evolutionary processes and associated landforms and habitat structures that are responsible for generating vertebrate species diversity in tropical rainforests.

Jeffrey H. Schwartz b. Mar. 6, 1948 in Richmond, VA, has a Ph.D. from Columbia University and is a professor of biological anthropology at the University of Pittsburgh. Whereas DNA evidence is strong that chimpanzees are humanity's closest relatives, Schwartz's 2005 revision of his book The Red Ape: Orangutans and Human Origins explores the two allied species' morphological similarities. And his four-volume treatise The Human Fossil Record (2005) coauthored with Ian Tattersall, sets a benchmark in comprehensive hominid documentation. Schwartz also works in forensic anthropology and has assisted efforts to reconstruct the appearance of George Washington.

Charles Sibley b. Aug. 17, 1917, Fresno, CA, d. 1998, Ph.D., U.C. Berkeley, was one of the most famous ornithologists of the twentieth century. Credited by one of his closest colleagues, Jon Ahlquist, with founding molecular systematics, even Ahlquist criticized Sibley's famously thorny personality. Working first at Cornell and later at Yale, Sibley's influential studies on natural hybridization in

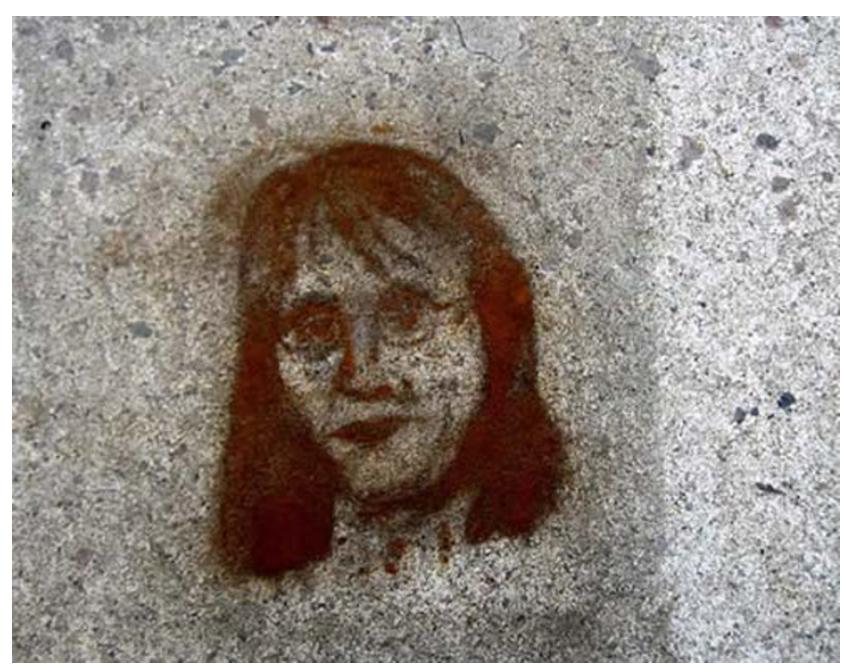

Fig. 11 Eugenie Scott by Esther Solondz (http://www.BU.edu/Darwin) birds applied DNA analysis to clarify bird classification. His important publications include Phylogeny and Classification of Birds (1991), written with Jon Ahlquist, and Distribution and Taxonomy of Birds of the World (1991), written with Burt Monroe.

George Gaylord Simpson b. Chicago, IL, 1902, d. 1984, was a leading American paleontologist who got his Ph.D. at Yale and worked first at the American Museum of Natural History, later at Harvard's Museum of Comparative Zoology. He is known, along with Ernst Mayr and Theodosius Dobzhansky, as one of the architects of the modern evolutionary synthesis in the U.S., and his works such as Tempo and Mode in Evolution (1944) and The Meaning of Evolution (1949) influenced an entire generation of evolutionary biologists.

John Maynard Smith b. Jan 6, 1920, London, England, d. 2004, studied genetics under J. B. S. Haldane at University College London. Smith is known for his seminal work in game theory, the evolution of sex, and signaling theory. This much-honored and respected geneticist was a founder and first dean of the School of Biological Sciences at Sussex University. He wrote many books applying game theory to evolutionary scenarios, showing that both dominant and minor strategies can coexist in the game of survival. His idea of the "evolutionarily stable strategy" clearly prefigures Richard Dawkins' work on the "selfish gene."

George Ledyard Stebbins b. Jan. 6, 1906, Lawrence, N.Y., d. Jan. 19, 2000, has been called the founder of evolutionary botany for his applications of the modern synthesis to plants. His influence on modern views of plant species and plant speciation is incalculable. He got interested in applying genetics to plants while working on his Ph.D. at Harvard, then met Theodosius Dobzhansky. After publishing his classic 1950 Variation and Evolution in Plants, he went to U.C. Davis and established its first Department of Genetics. He was a coauthor of the textbook Evolution (1977) with Theodosius Dobzhansky, Francisco Ayala, and James Valentine.

Nettie Stevens b. 1861, Cavendish, Vermont; d. 1912, was a brilliant scholar who graduated from Stanford University and took a Ph.D. in biology at Bryn Mawr College in 1903. Her undergraduate work in microscopic marine biology led to a scholarship in Europe under Theodor Bovari in Germany, studying the role of chromosomes in heredity. Granted an assistantship at the Carnegie Institute, she studied sex determination first in mealworms, then in many different insects. She held a teaching position there and was petitioning to become a full-time researcher when she died of breast cancer.

Shirley Tilghman b. Shirley Marie Caldwell, Sept. 7, 1946, Canada, Ph.D., Temple University, is now 19th president of Princeton University. During postdoctoral 
studies at the National Institutes of Health, she made a number of groundbreaking discoveries while participating in cloning the first mammalian gene. In 2002, Tilghman was one of five winners of the L'Oréal-UNESCO international Women in Science Award, and the following year received the Lifetime Achievement Award from the Society of Developmental Biology.

Nikolass Tinbergen b. April 15, 1907, The Hague, Holland, d. 1988, was an ethologist and ornithologist. He was a dedicated field observer who studied herring gulls intensively and related their violent behavior to human aggression. His 1951 book The Study of Instinct is considered his most important work. Tinbergen shared the 1973 Nobel Prize for Medicine with Karl von Frisch and Konrad Lorenz, having explored the importance of distinguishing the evolutionary roles of "proximate mechanisms" (causation and ontogeny) and "ultimate mechanisms" (adaptation and phylogeny). These basic mechanisms remain essential to the study of modern ethology and sociobiology.

Robert Trivers b. Feb. 19, 1943, Washington, D.C., holds a Ph. D. from Harvard. In the 1970s, Trivers published five major papers linking genetics to behavioral biology with a "selfish gene" model to explain behaviors from bird warning calls to cuckoldry to sibling rivalry to revenge. Among them was Parental Investment and Sexual Selection (1972). He won the 2007 Crafoord Prize in Biosciences for "his fundamental analysis of social evolution, conflict, and cooperation." E. O. Wilson, who coined the term sociobiology, called him one of the most influential theoretical evolutionary biologists of our time.

Harold Urey b. April 29, 1893, Walkerton, IN, d. 1981, held a Ph.D. from U.C. Berkeley. Through the repeated distillation of liquid hydrogen, Urey was the first to isolate deuterium, and his pioneering work on isotopes won him the 1934 Nobel Prize in Chemistry. During WWII, his work at Columbia University helped the Manhattan Project develop the atom bomb. His study of the chemical elements of Earth's atmosphere led to the conclusion that it was probably mostly hydrogen, methane, and ammonia, which inspired his graduate student Stanley L. Miller to demonstrate that such a mix, exposed to water and ultraviolet radiation and electric shock, can produce the "building blocks of life," amino acids.

Adrianna C. Ocampo Uria b. Colombia, wrote her masters thesis in geology at California State University Northridge on the 130-mile-wide Chicxulub Crater in the Yucutan Peninsula, which she discovered while scanning photos from space. This monumental asteroid impact may be what finished off the dinosaurs 65 million years ago. Uria has worked for the Jet Propulsion Laboratory at Cal Tech since 1973 and now holds a position in information services at NASA headquarters in Washington, DC.
Alfred Russel Wallace b. 1823 Usk, Wales, d. 1913, came from an English family of property who went broke. Wallace left school early to work outdoors with his brother as a surveyor and got hooked on the national beetlecollecting craze, leading to his career as a naturalist. $\mathrm{He}$ collected living plants and animals extensively in the Amazon and the Malay Archipelago, always searching for answers to the mystery of organic change. In 1855, he wrote a paper in Sarawak, Borneo, which laid out his view of biological evolution, although he did not connect Malthus and a "survival of the fittest" biological model until 1858, when he wrote of his discovery to his British contact, Charles Darwin, and they published jointly.

August Weissman b. January 17, 1834 in Frankfurt-amMain, Germany, d. 1914, began professional life as a physician, but by 1863 he was permanently established as a zoologist at Albert Ludwig University of Freiburg. Although the logic of famously cutting off the tails of 20 generations of mice - 1,500 individuals - proved faulty, his studies of inheritance of acquired traits helped finally lay to rest Lamarkian ideas of how evolution works. Before the advent of modern genetics - or even the rediscovery of Mendel's work-Weissman showed that only "germ cells" contain heritable information, whereas "somatic cells" merely keep the body functioning.

George C. Williams b. May 12, 1926, is the author of the classic book Adaptation and Natural Selection (1966). He was an early participant in developing a gene-centered view of evolution, and he was a resounding defender of Darwinian natural selection, as opposed to group selection theories current at the time. Williams won the Crafoord Prize for Bioscience jointly with Ernst Mayr and John Maynard Smith in 1999 and is a member of the National Academy of Sciences. He is now Professor Emeritus of Ecology and Evolution at State University of New York at Stony Brook.

Allan Wilson b. 1934 Nguarawahia, New Zealand d. 1991, left New Zealand in 1955 to pursue a Ph.D. at U.C. Berkeley and stayed to establish a renowned center for study of molecular evolution and originate the controversial idea of a "molecular clock" based on the observation that proteins and genes change at a steady rate over time. The idea helped to determine that man and apes split off a single lineage about 5 million years ago. One of the first scientists to apply DNA sequencing and PCR to the study of evolution, he is the father of the "mitochondrial Eve" hypothesis tracing all humanity through the maternal line back to one ancestor.

E. O. Wilson b. June 20, 1929, Birmingham, AL, got his Ph.D. at Harvard, and has been at the Museum of Comparative Zoology there for over 40 years. With his 1975 book Sociobiology: The New Synthesis, Wilson not only coined the term, he invented the entire field of 
sociobiology and stirred ire among critics of his arguments that human culture has strong biological components. His ant studies proved the existence of pheromones and showed that altruistic behavior is "selfish," as it helps the colony to survive. Wilson is a devoted environmentalist who sees a "sixth extinction" with humans, rather than nature, as the new agents of environmental destruction.

Carl Woese b. July 15, 1928, in Syracuse, NY, took a Ph.D. in biophysics at Yale. Currently Professor of Microbiology at the University of Illinois at UrbanaChampaign, he is much honored for his discovery of a third form of life - archea - in addition to eukaryotes and bacteria. Using the fact that rRNA shows only slight variation from one generation to the next, he discovered that some prokaryotes have structures dissimilar to bacteria, and perhaps more closely related to eukaryotes.

Richard Wrangham b. Nov. 8, 1948, has a Ph.D. from Cambridge. Now a biological anthropology professor at the Museum of Comparative Zoology (Harvard), Wrangham seeks clues to human evolution through the study of chimpanzee behavior. His book Demonic Males: Apes and the Origins of Human Violence (1997), written with Dale Peterson, explores the fact that chimps are the only animals besides humans that organize raids to stalk and kill members of their own species. Wrangham thinks cooking may date back as much as 2 million years, and that our large brains, small teeth, and tendency to long-term pairbonding may all be traced back to the first hot meals for hominids.

Sewall Wright b. Dec. 21, 1889, Melrose, MA, d. 1988, studied at Cold Spring Harbor before majoring in biology as an undergraduate. He got his Ph.D. in 1915 at Harvard working on mammalian genetics, mainly guinea pig coloration. Wright fathered the concept of genetic drift, also known as the "Sewall Wright effect"-recognizing that random processes, in addition to natural selection, may lead to gene fixation in populations. Wright's brilliant application of mathematical models to evolution made him a leading evolutionary researcher of the twentieth century and, with R.A. Fisher and J.B.S Haldane, creators of the modern evolutionary synthesis.

Milford Wolpoff b. 1942, Chicago, IL, Ph.D. 1969, University of Illinois, advocates a multiregional model of human origins that remains controversial among most physical anthropologists. Wolpoff believes there was not one single ancestor, but several different ones in different regions of the old world. The more conventional theory suggests all humanity descends from "Eve," a single African ancestor, some 200,000 years ago. Multiregional evolution theorizes that for about 2 million years humans have lived in several areas of the world and have evolved together because they met and interbred.

Xu Xing b. Xin Jiang, China, 1969, trained in the Geology Department of Peking University and now works at the Chinese Academy of Sciences in Beijing. His extensive field work, often in the company of American Museum of Natural History scientists, has uncovered many new finds, most recently, the 1.35-million-year-old Mei long, or "soundly sleeping dragon," which is a small dinosaur fossilized in a "tucked in" sleeping position similar to that of birds, further evidence of an evolutionary link between birds and dinosaurs. Experts theorize that small size was needed for flight and that the compact sleeping position helped conserve energy by reducing loss of body heat. 